\title{
A DEMOCRATIZAÇÃO BRASILEIRA um balanço do processo político desde a transição
}

\author{
Maria D'Alva G. Kinzo \\ Professora do Departamento de Ciência Política da USP
}

\begin{abstract}
Resumo: O objetivo do artigo é discutir a presente experiência democrática através de uma análise do caminho percorrido pelo processo de democratização brasileiro. A visão bastante crítica sobre tal experiência, presente no debate político atual, tem negligenciado o impacto que constrangimentos de várias naturezas tiveram sobre o processo de democratização. Uma análise retrospectiva que recupere as marchas e contramarchas da longa transição democrática ajuda a compreender alguns dos dilemas da atual conjuntura.

Palavras-chave: transição democrática; democratização brasileira; partidos políticos.
\end{abstract}

$\mathrm{A}$ presente conjuntura, marcada como tem sido por um suceder de crises políticas emaranhadas em outras de natureza econômica e social, tem levado muitos à percepção de que, se não chegamos a andar para trás, avançamos muito pouco na direção do aprimoramento democrático do sistema político brasileiro. A ineficácia dos governos em tratar de solucionar os problemas econômicos e sociais que afetam a porção majoritária da população brasileira, a onda de denúncias de práticas de corrupção em órgãos públicos, envolvendo lideranças políticas importantes, e a sensação de insegurança resultante não apenas da violência urbana, mas também de instabilidade econômica de várias naturezas, são elementos que se combinam para formar o pessimismo geral que se tem alastrado, em relação aos frutos desses anos de democracia no país. Para uma população que, em sua maioria, tem mostrado pouco apego aos valores democráticos - como várias pesquisas de opinião têm constatado -, esses fatores aludidos acabam ocultando os avanços democráticos conquistados nos últimos 16 anos. Por excesso de foco no presente, esquece-se do passado recente, ou trata-se de vê-lo desprovido de seus espinhos, e julga-se o presente sob a perspectiva de um modelo idealizado do sistema político. É em função desse desencanto frente ao quadro político atual que parece oportuno rememorar o caminho percorrido pela democratização brasileira para, a partir daí, avaliar o presente regime democrático. Não se trata aqui de contrastar o clima geral de pessimismo com um cenário oposto, de tonalidades vivas, do que tem sido conquistado em nossa experiência democrática. Trata-se, sim, de dar a devida ênfase aos aspectos tanto negativos como positivos à luz dos constrangimentos antepostos ao processo de liberalização política. Ou seja, procura-se valer do tão aludido conceito de path dependence para salientar a noção de que as opções políticas postas em uma determinada conjuntura resultaram de decisões precedentes -, escolhas feitas pelos atores relevantes -, as quais influenciaram o curso do processo político, a ponto de limitar o leque de opções numa conjuntura futura, e portanto os cursos de ação possíveis. Sob tal enfoque, a discussão sobre o cenário democrático atual requer, primeiramente, uma referência ao ponto de partida da democratização - isto é, o regime militar-autoritário que vigorou de 1964 a 1985 - bem como à dinâmica política que orientou a liberalização deste regime e sua transição para a democracia. Fazer uma retrospectiva deste processo será o objetivo deste artigo, que não tem qualquer pretensão de oferecer uma interpretação original sobre esta temática. A intenção é apenas de trazer ao presente um pouco de nosso passado recente, que tem sido negligenciado na maioria das análises que dão suporte ao debate político atual.

\section{GOVERNO MILITAR-AUTORITÁRIO}

Como já foi amplamente discutido na literatura, o caso brasileiro, comparado a outras experiências autoritárias 
vivenciadas na mesma época em outros países da América Latina, assentou-se sob alicerces singulares que merecem referência quando tratamos de analisar a influência de fatores de longo prazo no processo de democratização. ${ }^{1}$ Estas bases são de duas naturezas: uma tem a ver com as instituições políticas sob as quais o governo militar operava; e a outra, no domínio econômico, refere-se ao modelo de desenvolvimento seguido e suas conseqüências. No âmbito da política, há que se lembrar a emergência de uma situação bastante paradoxal. Por um lado, tratava-se de um regime tipicamente militar no sentido de que as Forças Armadas, enquanto instituição, passavam (após o golpe civil-militar que depôs João Goulart em 1964) a dirigir o país. Tal situação necessariamente levaria a que a instituição militar passasse a ser também uma arena de disputa pelo poder político, o que teria conseqüências não apenas na coesão interna da organização, mas também em toda a dinâmica política. Conflitos entre oficiais moderados e radicais permearam os 21 anos de governo militar gerando freqüente instabilidade política. Por outro lado, tratava-se de uma situação que manteve em funcionamento os mecanismos e os procedimentos de uma democracia representativa: o Congresso e o Judiciário continuaram em funcionamento, a despeito de terem seus poderes drasticamente reduzidos e de vários de seus membros serem expurgados; manteve-se a alternância na presidência da República; permaneceram as eleições periódicas, embora mantidas sob controles de várias naturezas; e os partidos políticos continuaram em funcionamento, apesar de a atividade partidária ser drasticamente limitada. Em síntese, era um arranjo que combinava traços característicos de um regime militar autoritário com outros típicos de um regime democrático. Este arranjo peculiar foi o responsável, em grande medida, por sucessivas crises políticas que acompanharam o regime, fazendo-o se caracterizar por fases alternadas de repressão e liberalização permeadas por crises políticas resultantes de conflitos dentro do exército e entre estes grupos e a oposição democrática (Kinzo, 1988). A instabilidade que acompanhou o governo dos militares no Brasil, indicativo da dificuldade de institucionalização do regime, levou Linz (1973) a caracterizar o autoritarismo brasileiro como uma situação em vez de um regime propriamente dito. Regime ou situação, o fato é que o estabelecimento desse arranjo político híbrido teve grande impacto na maneira como se deu a transição brasileira. Porém, antes de analisar o processo de transição, outra característica no modelo brasileiro, desta vez no âmbito econômico, deve ser apontada.
Em contraste com o que aconteceu, por exemplo, no Chile, onde o governo militar provocou uma mudança significativa no modelo econômico, no Brasil os militares não inovaram em matéria de política econômica. Com exceção dos três primeiros anos de governo militar, quando todos os esforços concentraram-se no programa de estabilização para conter as altas taxas de inflação, a política econômica, durante o período militar, seguiu basicamente o mesmo modelo vigente desde o governo Vargas. $\mathrm{O}$ chamado "milagre brasileiro" do período 1967-73 teve como sustentáculo, por um lado, os resultados obtidos pela política de estabilização de 1964-67 e, por outro, uma política de desenvolvimento que consolidou e intensificou o modelo de substituição de importações que reservava ao Estado um papel empreendedor ainda mais importante. Por volta de 1974, a despeito dos sinais de que o milagre havia se desfeito - manifestos pelo impacto que a crise mundial do petróleo exerceu no Brasil -, o mesmo caminho continuou a ser trilhado. Uma ambiciosa política de substituição de importações de bens de capital e matérias-primas, sustentada por investimentos do setor público e por empréstimos estrangeiros, foi a estratégia seguida (Cardoso, 1983). Certamente, esta estratégia teve êxito ao garantir altas taxas de investimento e ao fazer da experiência brasileira de regime militar-autoritário um caso de desempenho econômico bem-sucedido. Porém, foi também responsável por sérios desequilíbrios, e os problemas econômicos que haviam provocado a intervenção militar em 1964 - inflação alta e estagnação econômica ressurgiram com ainda mais intensidade, permanecendo como pano de fundo do processo de transição política. ${ }^{2}$

\section{A LONGA TRANSIÇÃO}

Não foi apenas o regime militar que, no Brasil, teve traços peculiares. Também singular foi seu processo de democratização. ${ }^{3}$ Tratou-se do caso mais longo de transição democrática: um processo lento e gradual de liberalização, em que se transcorreram 11 anos para que os civis retomassem o poder e outros cinco anos para que o presidente da República fosse eleito por voto popular. Para propósito analítico, pode-se dividir este processo em três fases. A primeira, de 1974 a 1982, é o período em que a dinâmica política da transição estava sob total controle dos militares, mais parecendo uma tentativa de reforma do regime do que os primeiros passos de uma transição democrática de fato. A segunda fase, de 1982 a 1985, é também caracterizada pelo domínio militar, mas outros 
atores - civis - passam a ter um papel importante no processo político. Na terceira fase, de 1985 a 1989, os militares deixam de deter o papel principal (apesar de manterem algum poder de veto), sendo substituídos pelos políticos civis, havendo também a participação dos setores organizados da sociedade civil. Como estas fases possuem diferentes componentes e dinâmicas resultantes do jogo dos principais atores políticos, uma análise com algum detalhe faz-se necessária.

\section{Primeira Fase: 1974 a 1982}

A ascensão do general Geisel na presidência da República, em 1974, e o anúncio de seu projeto de distensão "gradual e segura" marcaram o início de um novo período do governo militar-autoritário, uma fase que passaria a ser o ponto de partida do processo de democratização no Brasil. A revogação parcial da censura à imprensa e os sinais, por parte do governo, de valorização das eleições legislativas daquele ano (1974) indicavam que as declarações do novo presidente eram algo mais do que promessas de retorno à democracia tão freqüentemente aludidas por seus antecessores na presidência. ${ }^{4} \mathrm{O}$ modo como este projeto de liberalização foi conduzido e a dinâmica do processo político que acabou por levar à democracia foram, no entanto, algo extremamente complicado. Esta fase da transição foi totalmente conduzida pelo governo militar, que definiu tanto seu ritmo como seu escopo. Entretanto, vários fatores influenciaram o curso deste processo.

O primeiro fator foram as eleições. Os sinais de liberalização que permitiram a realização das eleições de 1974 em condições mais livres resultaram num surpreendente desempenho eleitoral do partido de oposição (MDB). Com isso, ficava evidente que, a despeito dos excelentes resultados econômicos conseguidos sob regime militar, este carecia de apoio popular. Também ficava claro que o inofensivo MDB, criado para ser parceiro da Arena no bipartidarismo de fachada instituído pelo regime, havia se tornado um instrumento efetivo de oposição democrática, a ser utilizado não apenas na arena eleitoral, mas também no processo político mais amplo, de modo que, se a política de liberalização deveria ser mantida sob controle do governo, esta tinha que neutralizar tanto as eleições como o MDB (Lamounier, 1988 e Kinzo, 1988).

O segundo fator era a instituição militar e seu conflito interno. Na realidade, uma das principais razões que explicam a iniciativa do governo de iniciar a liberalização é a necessidade de os militares se retirarem da vida política a fim de preservar a própria instituição. ${ }^{5}$ Porém, a iniciativa de Geisel intensificaria o conflito dentro das Forças Armadas, tornando mais agressiva a reação da chamada linha-dura contra a abertura do regime. A intensificação na repressão policial, empreendida pela linha-dura no comando militar de São Paulo em 1975-76, foi claramente uma reação à política de liberalização de Geisel. Tratava-se, portanto, de neutralizar as pressões internas dos militares contra a distensão, de modo que eles não minassem o comando político de Geisel e tampouco interferissem, mais tarde, na questão crucial que seria a sucessão presidencial.

Geisel foi bem-sucedido ao lidar com ambos os problemas, jogando nas duas direções ao mesmo tempo: de um lado, puniu com a cassação do mandato alguns dos parlamentares de postura oposicionista mais aguerrida, alterou leis eleitorais e procedimentos legislativos para controlar a oposição, apaziguando assim os militares da linha-dura, ao mesmo tempo em que reafirmava seu controle sobre a oposição democrática; de outro lado, reagiu à radicalização dos militares da linha dura, demitindo o comandante das Forças Armadas de São Paulo após a morte por tortura de um jornalista e de um trabalhador metalúrgico, nas dependências dos órgãos de repressão. Reafirmando assim seu comando absoluto sobre o processo político, Geisel conseguiu não apenas dar continuidade à política de distensão, como também controlar o processo sucessório.

Deste modo, ao final de 1978, reformas políticas de cunho liberalizante foram implementadas de acordo com o caráter gradual e seguro da política de distensão. Um novo presidente, general João Figueiredo, encarregado de dar continuidade à transição política nos seis anos seguintes, havia sido eleito estritamente de acordo com a determinação de Geisel de impor o nome por ele escolhido.

Se Geisel foi extremamente habilidoso ao tratar com potenciais opositores a seus objetivos políticos, não teve a mesma habilidade para lidar com um terceiro fator que influenciou o processo de liberalização política: o problema econômico. Várias eram as evidências de que o "milagre econômico" brasileiro estava se esgotando. ${ }^{6} \mathrm{O}$ problema econômico era certamente um elemento crucial a ser levado em conta se os militares quisessem retornar aos quartéis com segurança. Ao que parece, considerações de natureza política foram fundamentais no modo como Geisel decidiu lidar com a primeira crise mundial de petróleo e suas conseqüências recessivas. Em vez de optar pela contração econômica, como aconteceu na maioria dos países afetados pela crise, o 
governo Geisel implementou uma política de expansão econômica através do aprofundamento do modelo de substituição de importações, em detrimento dos conseqüentes desequilíbrios internos e externos. Assim, um ambicioso programa de substituição de importações nos setores de matéria-prima e bens de capital foi implantado, envolvendo investimento estatal significativo nos setores de energia e infra-estrutura às custas de grandes empréstimos estrangeiros. O curso desta política não foi revertida durante os primeiros anos da administração Figueiredo, o que significava que, enquanto a economia expandia, as contas externas e a inflação continuavam a crescer. O agravamento dos problemas externos obrigou a equipe econômica de Figueiredo a mudar radicalmente a política econômica. Uma tentativa de reajuste econômico foi pela primeira vez implementada, gerando uma queda brusca na atividade econômica e aumentando o desemprego. Outro choque externo em 1982 agravou ainda mais o cenário econômico extremamente vulnerável às mudanças no ambiente externo (Lamounier e Moura, 1986). A partir daí a crise econômica acompanharia passo a passo a transição política e os governos democráticos que lhe seguiram.

Em suma, os três fatores apontados - o processo eleitoral, o conflito interno dentro das forças armadas e a emergência de sérios problemas econômicos - concorreram para fortalecer aquele padrão controlado e gradual que caracterizou a transição democrática no Brasil. Iniciada em 1974, a liberalização somente teve um avanço significativo em 1978, quando finalmente foi revogado o draconiano Ato Institucional n.5. Em 1979, já na administração Figueiredo, o Congresso aprovou a anistia, que, embora limitada, permitiu a reintegração à vida pública de políticos exilados e de ativistas de esquerda punidos pelo regime militar. Uma nova lei partidária pôs fim ao bipartidarismo compulsório criado em 1966, levando à criação de novos partidos.

A reforma partidária representou importante avanço no processo de liberalização, mas foi também uma estratégia do governo para dividir a oposição e assim manter a transição sob controle. Entre os fatores a serem controlados estava a sucessão presidencial de 1985, que deveria possibilitar o restabelecimento do governo civil. Tratava-se de garantir não apenas que o próximo presidente fosse eleito via Colégio Eleitoral (e não por sufrágio universal), mas também a maioria governista no Colégio Eleitoral. Assim, alteraram-se as regras eleitorais e mesmo a composição do Colégio Eleitoral, de forma a reduzir as chances de a oposição obter a maioria.

\section{Segunda Fase: 1982 a 1985}

Apesar dos percalços, o processo de liberalização teve continuidade, iniciando uma nova fase com as eleições de 1982. Novos partidos políticos haviam sido criados e participado das eleições. Políticos que nos anos 60 tinham perdido seus direitos voltaram à vida pública e, pela primeira vez desde 1965, governadores estaduais foram eleitos pelo voto popular. Naquelas eleições, o governo militar teve importantes ganhos, assegurando sua maioria no Colégio Eleitoral que elegeria o próximo presidente. Porém, também a oposição obteve avanços significativos, particularmente o PMDB, que elegeu os governadores e senadores de nove Estados e conquistou 200 cadeiras na Câmara dos Deputados. Assim, apesar de os militares continuarem em sua posição inquestionável de jogador principal, outros atores passariam, a partir de 1982, a influenciar o jogo, atrapalhando os planos do governo de manter o controle total sobre o processo político.

O episódio mais importante foi a sucessão presidencial, a qual deve ser analisada como uma peça em dois atos. O primeiro seria a tentativa do PMDB, em 1984, de mudar as regras das eleições presidenciais, propondo uma emenda constitucional que restabelecesse o voto direto. Com o objetivo de obter apoio popular para a aprovação da emenda, os partidos de oposição partiram para a mobilização da população. O resultado da campanha das "Diretas Já" foi uma impressionante mobilização popular com milhões de pessoas participando de comícios em todo o país. Observando-se aquela mobilização, a impressão era de que a sociedade civil - que havia mostrado sua existência nos movimentos sociais surgidos em 1978 - tinha decididamente despertado e, finalmente, alteraria o curso da liberalização. Essa foi, na verdade, a percepção de alguns setores da oposição democrática, mas a emenda foi derrotada no Congresso, uma vez que a pressão popular não foi eficaz o suficiente para fazer frente a todas as manobras usadas pelo governo para evitar sua aprovação.

O desfecho deste episódio colocou mais uma vez em evidência que os militares estavam determinados a manter, a qualquer custo, o controle sobre o processo sucessório presidencial. Ficou também evidente que, apesar do apoio da mobilização popular, a oposição era numericamente muito fraca no Congresso para ser capaz de desafiar o regime se fosse para continuar jogando dentro das regras estabelecidas. À oposição restava duas saídas: buscar simpatizantes dissidentes dentro do governo; ou romper as regras do jogo através da mobilização da sociedade civil. A decisão de qual 
direção seguir dependia da posição e força relativa de cada um dos diferentes grupos da oposição, ou seja, o PMDB com suas divisões internas, o PT, o PDT e o PTB. Do PTB se esperava pouco de oposicionismo, dado que havia votado contra a emenda das diretas em troca de cargos no governo. O PDT, por sua vez, era imprevisível, uma vez que seu líder, Leonel Brizola, chegara a propor a prorrogação do mandato presidencial de Figueiredo em troca de eleições diretas para seu sucessor. Deste modo, restaram apenas dois atores principais: a favor da primeira alternativa estava o PMDB, mais especificamente sua ala moderada, que era a mais numerosa e liderava o partido; a favor da segunda estava o PT, seguido por um pequeno grupo de parlamentares do PMDB que mantinham relações mais próximas com os movimentos sociais.

A decisão do PMDB de optar pela primeira alternativa - isto é, tentar influenciar o processo sucessório jogando conforme as regras estabelecidas - foi o segundo ato da sucessão presidencial. Sem dúvida era o produto da posição moderada dos líderes do partido, para quem uma solução negociada evitaria a imprevisibilidade e os riscos de uma mobilização popular e, conseqüentemente, a reação por parte dos militares da linha-dura contra qualquer tentativa de mudança radical. ${ }^{7}$ De qualquer modo, os líderes do PMDB estavam dispostos a participar do processo sucessório mesmo que em condições limitadas. De fato, enquanto o PMDB trabalhava pela campanha pródiretas, a ala moderada do partido já articulava uma estratégia alternativa caso a emenda não passasse no Congresso. A proposta era a candidatura Tancredo Neves para concorrer pela oposição na eleição pelo Colégio Eleitoral, alternativa que ganhou força tão logo foi derrotada a Emenda das Diretas. Entretanto, viabilizar a candidatura de Tancredo Neves não era uma tarefa simples, uma vez que, para seu êxito, era necessário conseguir o apoio do outro lado, ou seja, de parlamentares do partido do governo. A oportunidade surgiu quando alguns políticos do PDS recusaram-se a apoiar o candidato do governo nomeado na convenção do partido. Negociações entre o PMDB e dissidentes do partido do governo (que depois criariam o PFL) levaram à formação da Aliança Democrática, cujo objetivo era juntar forças para derrotar o candidato do governo. Em troca do apoio dos dissidentes à candidatura Tancredo Neves, o senador José Sarney foi escolhido para ser candidato a vice-presidente na chapa da oposição.

A estratégia adotada pela oposição moderada certamente logrou êxito, pois o governo militar foi impossibilitado de impor seu candidato, mas teve duas conse- qüências importantes: possibilitou que os dissidentes do regime autoritário desempenhassem um papel importante no novo regime - na verdade passariam a ser parceiros de todos os governos que se seguiram; e abriu um amplo espaço para as críticas dos setores mais radicais da oposição, mais especificamente o PT, contrários à participação no processo indireto da eleição presidencial. Sob o argumento de que o Colégio Eleitoral era ilegítimo e não representativo, os parlamentares do PT foram orientados a não participar da escolha do sucessor de Figueiredo. Como o número de votos do PT no Colégio Eleitoral não era decisivo, certamente era mais lucrativo posicionar-se contra a transição negociada, diferenciando-se assim da oposição moderada e afirmando sua própria identidade mais à esquerda no sistema político que emergia. O problema, entretanto, estava no fato de que, ao denunciar as limitações da "transição negociada", esta estratégia contribuiu para que a nova ordem instaurada em 1985 desse seus primeiros passos com sua legitimidade já questionada.

\section{Terceira Fase: 1985 a 1990}

A segunda fase da transição findou-se com a eleição de Tancredo Neves e José Sarney, em 15 de janeiro de 1985. Porém, a inauguração de seu governo - que deu início à terceira fase da transição - sofreria ainda o efeito do acaso: a doença repentina de Tancredo, seguida de sua morte, levando à posse do vice, José Sarney, na presidência da República. Como conseqüência, além de a Nova República - como passou a ser chamado o restabelecimento do governo civil - ter resultado de um acordo entre setores moderados da oposição e dissidentes do governo, sem o respaldo do voto popular, com a morte de Tancredo um outro complicador iria se antepor à democratização. Significava que a Nova República nascia sob circunstâncias bastante frágeis, especialmente para um presidente que teria de enfrentar uma crise econômica e social que se avolumava. Assim, Sarney tomou posse sem um plano de governo propriamente dito e com um sério déficit em legitimidade: uma figura política marcada por anos de vínculos com os militares, que assumia o poder sem o respaldo das urnas e que não era das fileiras do partido que esperava desta vez governar - o PMDB. ${ }^{8}$ Estes fatores dificultaram sua administração, que ficou vulnerável a todos os tipos de pressão - desde as forças políticas heterogêneas que compunham seu governo (cada uma tentando aumentar sua influência) até os partidos de oposição e 
os setores organizados da sociedade civil demandando pronta democratização em todos os sentidos do termo.

A despeito destes problemas, a democratização brasileira seguiu seu curso neste novo contexto político. No que tange à questão social e econômica, o caminho percorrido foi de pedras e espinhos no período que se seguiu: entre 1986 e 1994 o país mudou quatro vezes de moeda e teve seis experimentos em estabilização econômica, apenas o último - o Plano Real - tendo sido bem-sucedido. A sucessão de fracassos não apenas agravou a crise econômica e social, mas também comprometeu a capacidade do Estado de governar, tornando o problema da governabilidade uma realidade permanente.

No que tange à esfera política, a fase inaugurada em 1985 foi de intensificação da democratização. Os sinais mais importantes foram a instituição de condições livres de participação e contestação (com a revogação de todas as medidas que limitavam o direito de voto e de organização política) e, acima de tudo, a refundação da estrutura constitucional brasileira com a promulgação de uma nova Constituição em 1988.

A elaboração da Constituição de 1988, vale lembrar, foi ilustrativa da complexidade que cercou o processo de democratização brasileiro. Do início ao fim, o processo envolveu um embate entre os mais variados grupos, cada um tentando aumentar ou restringir os limites do arranjo social, econômico e político a ser estabelecido. Na verdade, este clima de batalha verbal e de manobras nos bastidores era, em grande medida, um efeito colateral do curso da transição. Uma refundação que se apoiava num acordo negociado seria pressionada em duas direções: de um lado, pelas forças políticas do ancién regime tentando assegurar seu espaço neste novo cenário; e de outro, pelos setores de esquerda que, embora minoritários, adquiriram importante papel no processo constituinte. A pecha de ser uma transição negociada acabou fazendo com que seus condutores - líderes políticos moderados mas democratas - se tornassem mais vulneráveis às críticas quanto às limitações do novo regime e, por conseguinte, mais sensíveis às pressões das forças políticas que clamavam pelo aprofundamento da democratização. Em função deste fator, é provável que a estrutura constitucional tenha se tornado muito mais democrática do que se esperaria das circunstâncias de um processo de transição tão gradual e controlado como foi o brasileiro, pois, a despeito de a Assembléia Constituinte ter sido amplamente criticada na época por sua natureza congressual, foi certamente a experiência mais democrática na história constitucional bra- sileira. No que se refere aos procedimentos que nortearam sua elaboração, vários pontos devem ser assinalados:

- os trabalhos foram organizados sob uma estrutura bastante descentralizada, de modo que todos os constituintes tivessem garantida sua participação nas diversas fases do processo;

- ao invés de um trabalho a portas fechadas, houve ampla abertura para a sociedade, uma vez que foi um processo não só intensamente coberto, a cada passo, pela imprensa, mas que também contou com a participação dos grupos sociais organizados, seja diretamente, através de demandas e sugestões na fase de trabalho das subcomissões, seja indiretamente, por meio de pressão para que suas propostas fossem aprovadas pelo plenário;

- dado que as forças políticas encontravam-se fragmentadas e os partidos escassamente organizados, a Constituinte se tornou bastante permeável às pressões dos interesses de grupo, sendo que a decisão da maioria era precedida de longas negociações a cerca de praticamente cada item específico. ${ }^{9}$

No que se refere ao produto, a despeito de várias imperfeições, a Constituição representou um avanço significativo. Todos os mecanismos de uma democracia representativa foram garantidos, mesmo aqueles associados à democracia direta, como o plebiscito, o referendo e o direito da população de proposição de projeto de lei. Além disso, desconcentrou-se o poder em conseqüência do fortalecimento do poder do Legislativo, do Judiciário e dos níveis subnacionais de governo, bem como da total liberdade de organização partidária. Do âmbito social, a Carta de 1988 significou importantes avanços nos direitos trabalhistas, bem como nos padrões de proteção social sob um modelo mais igualitário e universalista (Castro, 1993). A Constituição também foi inovadora em relação às minorias, com a introdução de penalidades rigorosas para discriminações contra mulheres e negros. No entanto, dado o contexto social e político no qual se processou a reconstitucionalização do país, o novo estava fadado a conviver com o velho. Este foi o caso do secular problema agrário, que permaneceu quase intocado, e dos militares, que mantiveram sua prerrogativa de poder intervir, caso solicitado por um dos três poderes, na eventualidade de uma grave crise política. O legado da era Vargas foi também reafirmado pela Constituição, na inclinação nacionalista $\mathrm{e}$ estatista de algumas de suas cláusulas econômicas e na preservação de muitos dos traços característicos da estrutura corporativa de representação de interesses. ${ }^{10}$ 
A eleição de 1989 - quando 72 milhões de eleitores foram às urnas para eleger o presidente da República finalmente encerrou a terceira e última fase da transição brasileira. A posse de Collor marcava, simbolicamente, o final de um longo e complicado processo de transição democrática. Porém, os desdobramentos políticos que se seguiram demonstraram que a democracia emergente teve ainda que passar por vários testes antes de chegar na presente situação. Entre os fatos marcantes que tornaram o período uma sucessão de crises econômicas e políticas, alguns merecem destaque:

- as drásticas medidas econômicas do Plano Collor decretadas no dia seguinte à sua posse - políticas que, apesar de sua radicalidade em interferir arbitrariamente na poupança popular e investimentos financeiros e em promover ampla liberalização comercial, logo se mostraram ineficazes para conter a crise, levando à rápida erosão do apoio popular do primeiro presidente eleito pelo voto direto;

- impeachment do presidente Collor em 1992, resultante de sérias denúncias de corrupção, seguidas por uma expressiva mobilização popular e da ação decisiva do Congresso Nacional em solucionar a crise política;

- ascensão à presidência do vice, Itamar Franco, cuja liderança vacilante contribuiu ainda mais para agravar a incerteza política e econômica no país;

- realização de um plebiscito, em 1993, para definir se o país continuava presidencialista ou adotava o parlamentarismo como sistema de governo;

- tentativa de revisão constitucional em 1994, que se arrastou por meses e praticamente nada alterou, embora a necessidade de algumas mudanças constitucionais fosse demanda de muitos setores políticos;

- a famosa CPI do Orçamento, que pôs a público a deslavada prática de corrupção de alguns membros da Comissão de Orçamento do Congresso;

- implementação, em 1993-94, do Plano Real - um arrojado plano de estabilização econômica que finalmente conseguiu driblar a inflação;

- eleição presidencial de 1994, que acabou se transformando num plebiscito sobre a política econômica do governo, elegendo assim Fernando Henrique Cardoso - arquiteto do Plano Real;

- sucessão de crises econômicas no mundo afora - México em 1995, Ásia em 1997, Rússia em 1998 - cujo impacto no Brasil quase enterrou os esforços de estabilização do Plano Real e a popularidade de Fernando Henrique Cardoso;
- realização, em 1998, sob o impacto da crise russa, da terceira eleição presidencial, cujo desfecho foi a recondução de Fernando Henrique Cardoso para um segundo mandato presidencial.

Todos estes fatos foram desafios enfrentados por um regime ainda em processo de consolidação. Ao longo desses anos, eleições dos mais diferentes tipos e para os mais variados cargos continuaram a ocorrer com regularidade e com razoável grau de incerteza quanto aos resultados, indicando a vitalidade da democracia no que ela contém de controle popular sobre o exercício da representação política. Por outro lado, montanhas de escândalos de corrupção têm recheado as páginas dos jornais; denúncias de violência e atentado aos direitos da cidadania têm sido noticiadas diariamente; erupções de protestos e mobilizações de diferentes naturezas têm ocorrido em vários pontos do país. Eventos como estes tornaram-se parte do diaa-dia da vida democrática brasileira, que, a despeito desses problemas, obteve conquistas significativas.

\section{DEMOCRACIA ENTRE CONQUISTAS E LIMITAÇÕES}

O retrospecto do processo de democratização brasileiro aqui realizado tratou de percorrer o curso da transição em cada um de seus momentos fundamentais, avaliando esta experiência de forma a melhor entender os avanços $\mathrm{e}$ as limitações do presente sistema político. Como de resto tem ocorrido em outros momentos de nossa história, a democratização que se iniciou com a restauração do governo civil não foi o produto de uma ruptura com a antiga ordem. Isto implica que a reconstrução do sistema político deu-se através de acomodações e do entrelaçamento de práticas e estruturas novas e antigas, combinação esta que estruturou as opções e estratégias seguidas pelos principais atores do processo político. Salientar este ponto não significa desconsiderar os avanços democráticos conquistados, os quais são, em grande medida, o produto da dinâmica política introduzida pelo próprio processo de democratização.

Observando o sistema político no Brasil de hoje, não há como negar que se trata de um regime com claros contornos de uma democracia. Ao serem tomadas como referência as duas dimensões da poliarquia caracterizadas por Dahl (1971), o país ampliou significativamente as condições de contestação pública e participação política. Porém, tampouco há como negar que existam problemas no que se refere tanto à "qualidade" da contestação pública e 
da participação do cidadão quanto ao funcionamento efetivo do processo decisório democrático.

Vale lembrar, em primeiro lugar, a questão social, isto é, o problema da pobreza e da desigualdade. Não resta a menor dúvida de que extremas desigualdades sociais são um fator que constrange a consolidação da democracia, especialmente no que se refere è efetiva participação política de todos os cidadãos. Os elevados índices de pobreza e de concentração de renda no Brasil são um legado do passado que os governos pós-regime militar não tornaram menos agudo, ${ }^{11}$ a despeito de avanços na área da educação. Em segundo lugar, há problemas referentes à representação política e ao processo de decisão democrático. A estrutura institucional brasileira possui vários aspectos que dificultam o funcionamento do sistema democráticorepresentativo. ${ }^{12}$ Entre eles, vale destacar a tão debatida questão partidária, que se resume na existência de um sistema partidário que é, por um lado, altamente fragmentado e, por outro, pouco nítido no que tange às opções oferecidas ao eleitor no processo eleitoral. ${ }^{13}$ Trata-se de um contexto político que dificulta enormemente a capacidade do eleitor de fixar as legendas, distinguir quem é quem na competição e criar identidades partidárias. ${ }^{14}$ Quanto à questão da representação política, este é um contexto que possibilita a eleição de representantes pouco comprometidos com seu partido e com os eleitores que os elegeram, mesmo porque muitos se elegeram com os votos excedentes dos candidatos mais votados, os quais podem ser de um outro partido pertencente à coligação eleitoral.

Efeito também da alta fragmentação é a impossibilidade de que um presidente saia das urnas com um apoio partidário-parlamentar majoritário, o que o obriga a fazer um governo de coalizão de vários partidos. Isto significa que, a fim de manter uma base parlamentar de apoio a suas políticas, o chefe do governo terá de compor seu ministério com diferentes forças partidárias, por vezes heterogêneas, fator que certamente dificulta uma ação governamental coordenada, especialmente em relação a políticas públicas cuja implementação depende da ação de vários ministérios. Além disso, na medida em que o Executivo tem de contar com o apoio de vários partidos para ver seus projetos aprovados no Congresso, o processo de negociação é complexo e demorado, ou seja, envolve uma dinâmica difícil entre o presidente e os partidos da coalizão, muitas vezes baseada na ameaça e na retaliação mútua.

A tese de que a fragmentação partidária tem impacto negativo no processo decisório é contestada por Figueiredo e Limongi (1994) com base em análise das votações na
Câmara dos Deputados. Para estes autores, a existência de um sistema partidário fragmentado não teria conseqüências, uma vez que a fragmentação partidária é mais nominal do que real, dada a ocorrência de uma reaglutinação nas posições dos partidos. As evidências desse trabalho baseado em análise acurada das votações de projetos tramitados na Câmara dos Deputados - demonstram que os partidos de direita (grandes e pequenos) votam similarmente e os de esquerda fazem o mesmo, sendo que o grau de coesão é também alto. De fato, pelo que se observou sobre os partidos na Constituinte e sobre o posicionamento dos deputados estaduais da legislatura 1987-91, não há diferenças contrastantes entre os vários partidos de direita ou entre os vários de esquerda, havendo sim uma gradação de mais ou menos direita e mais ou menos esquerda (Kinzo, 1990 e 1993). No entanto, há que se fazer duas ressalvas. Em primeiro lugar, se é verdade que os partidos de direita assumem posições similares, ou não se diferenciam em questões essenciais, e se o mesmo ocorre com os de centro e os de esquerda, qual a relevância de existirem tantos partidos que ocupam semelhantes posições no espectro político-ideológico, mesmo porque também nas eleições eles se apresentam em aliança? A segunda ressalva tem a ver com as conseqüências da fragmentação sobre o processo decisório propriamente dito: a despeito de muitos dos partidos serem parecidos e, quando examinamos os resultados das votações, podermos ver menos partidos do que os nominais, o fato é que, na hora de negociar, eles o fazem como atores distintos, de modo que a situação continua sendo a de um jogo de poder fragmentado.

Em suma, o que predomina é uma situação em que o processo de decisão é dificultado pela existência de um sistema de múltiplos vetos, fazendo com que qualquer negociação envolva muitos atores e seja portanto árdua $\mathrm{e}$ demorada, situação muito mais propícia à manutenção do status quo do que à mudança de políticas. ${ }^{15} \mathrm{Em}$ tal contexto, qualquer que seja o perfil do presidente e de seu partido, a probabilidade de reforma efetiva em políticas públicas é limitada. Na presente experiência de governo democrático pós-85, o chamado presidencialismo de coalizão (Abranches, 1988) tem funcionado às custas do recurso, por parte do Executivo, seja de mecanismos de decisão concentradores de poder, como é o caso das Medidas Provisórias, ${ }^{16}$ seja de recursos clientelísticos para negociar apoio parlamentar em bases às vezes até individuais. A permanência desta situação, que reproduz à enésima potência o sistema de contrapesos do modelo 
madsoniano, pode ser entendida como fruto da acomodação possível no contexto de um padrão de desenvolvimento político como o descrito anteriormente. Isto não retira seu caráter problemático, especialmente num país em que a agenda política é carregada de problemas estruturais a serem equacionados.

\section{NOTAS}

E-mail da autora: mdkinzo@usp.br

1. Para uma revisão geral da experiência militar-autoritária no Brasil ver Cardoso (1972), Stepan (1973, 1975 e 1988) e Skidmore (1988).

2. É vasta a literatura sobre a economia brasileira durante o regime militar. Os comentários aqui são baseados nos trabalhos de Serra (1982), Fishlow (1973), Suzigan (1974) e Longo (1993).

3. Sobre a transição brasileira, veja Martins (1986), Stepan (1989), Lamounier (1988 e 1989), Velasco e Cruz e Martins (1983) e Diniz (1985).

4. Um balanço das diferentes abordagens explicativas da abertura política encontra-se em Figueiredo e Cheibub (1982) e Diniz (1985). Sobre o início da transição, ver também a excelente análise de Lamounier (1979).

5. Como Rouquié (1982:3) observou "um sistema permanente de domínio militar é quase uma contradição em termos. A instituição militar não pode governar de forma direta e duradoura sem deixar de sê-la".

6. Desaceleração do PIB, que caiu de $14 \%$ em 1973 para 9,8\% em 1974 e $5,6 \%$ no ano seguinte, aumento significativo do déficit em conta corrente (de US\$ 1,7 bilhão em 1973 para US\$ 7,1 bilhões em 1974) e crescimento da dívida externa (de US\$ 6,2 bilhões em 1973 para US\$ 11,9 bilhões em 1974, alcançando US\$ 56,3 bilhões em 1981) Serra (1982).

7. É bem provável que o processo político teria caminhado em outra direção caso tivesse sido seguido o segundo curso de ação, defendido pelos setores mais radicais da oposição. De qualquer forma, a democratização tanto poderia ter sido de outra natureza como poderia ter sofrido uma reversão autoritária.

8. Recorde-se que José Sarney filiou-se ao PMDB apenas para que pudesse concorrer à vice-presidência, dado que havia se desligado do PDS e o PFL ainda não havia sido fundado.

9. Sobre a Constituição de 1988, ver Souza e Lamounier (1990).

10. Como assinala Sallum Jr. (1999:27), "apesar de decadente, o modelo nacional-desenvolvimentista (certamente sob vestes mais democráticas) foi juridicamente consolidado pela Constituição de 1988".

11. Sobre esta questão ver Barros et alii (2000).

12. Sobre esta questão ver, especialmente, Lamounier (1992); Kinzo (1997) e Couto (2000).

13. Antes de um simples produto do sistema de representação proporcional, esta situação tem a ver com uma legislação partidária e eleitoral que possibilita alianças partidárias até mesmo nas eleições proporcionais, garantindo acesso ao horário eleitoral gratuito mesmo a partidos sem nenhuma expressão política, e com a desvinculação partidária do mandato eleitoral, isto é, a ausência de qualquer impedimento para troca de agremiação partidária de um detentor de mandato eletivo.

14. Como vários estudos têm indicado, a volatilidade eleitoral no Brasil, embora decrescente, é ainda bastante acima da média encontrada nas democracias consolidadas. Sobre a volatilidade eleitoral no Brasil, ver Nicolau (1998) e Peres (2000).

15. De acordo com Tsebelis (1995), a probabilidade de mudança do status quo é uma função não apenas do número de veto players, ou seja, atores institucionais e partidários com capacidade de vetar uma proposição, mas também da coesão de cada ator coletivo. No caso brasileiro, pode-se dizer que, dado que os partidos da presente coalizão governamental nem sempre se apresentam com alta coesão, no sentido de compartilhar posições ou princípios definidos e claros, são possivelmente mais propensos à negociação embora a dificultem o mais que puderem.

16. O poder do Executivo não se limita às Medidas Provisórias, uma vez que também detém a prerrogativa exclusiva de iniciativa legislativa em várias matérias, entre elas as referentes ao orçamento federal. Além disso, o Executivo pode interferir na agenda legislativa, solicitando ao colégio de líderes urgência na tramitação de uma matéria de seu interesse. Ver Figueiredo e Limongi (1994).

\section{REFERÊNCIAS BIBLIOGRÁFICAS}

ABRANCHES, S. "Presidencialismo de coalizão: o dilema institucional brasileiro". Dados, v.31, n.1, 1988, p.5-34.

BARROS, R.P. et alii. "Desigualdade e pobreza no Brasil: história de uma estabilidade inaceitável". Revista Brasileira de Ciências Sociais, v.15, n.42, 2000, p.123-42.

CARDOSO, F.H. O modelo político brasileiro. São Paulo, Difel, 1972.

" "O papel dos empresários no processo de transição: o caso brasileiro". Dados, v.26, n.1, 1983, p.9-27

CASTRO, M.H.G. "Democratic transition and social policy in Brazil: some dilemmas in the agenda of reforms". In: KINZO, M.D.G. (ed.). Brazil: the challenges of the 1990's. Londres, British Academic Press, 1993.

COUTO, C.G. Os mecanismos da governabilidade - Sistema de governo e democracia no Brasil. Tese de Doutorado. São Paulo, Universidade de São Paulo, 2000.

DAHL, R. Poliarchy: participation and opposition. New Haven, University Yale Ed., 1971.

DINIZ, E. "A transição política no Brasil: uma reavaliação da dinâmica da abertura". Dados, n.3, 1985, p.329-46.

FIGUEIREDO, A. e LIMONGI, F. "O Congresso e as Medidas Provisórias: abdicação ou delegação?” Novos Estudos Cebrap. São Paulo, n.47, 1997, p.127-154.

. "O processo legislativo e a produção legal no Congresso Pós-Constituinte". Novos Estudos Cebrap. São Paulo, n.38, 1994.

FIGUEIREDO, M. e CHEIBUB, J.A.B. "A abertura política de 1973 a 1981: quem disse o quê, quando - Inventário de um debate". $B I B$, n.14, 1982, p.29-61.

FISHLOW, A. "Some reflections on post 1964 brazilian economic policy". In: STEPAN, A. (ed.). Op. cit., 1973.

KINZO, M.D.G. Oposição e autoritarismo - Gênese e trajetória do MDB, 1966-79. São Paulo, Idesp/Vértice, 1988.

. "O quadro partidário e a Constituinte". In: LAMOUNIER, B. (org.). De Geisel a Collor: o Balanço da Transição. São Paulo, Editora Sumaré, 1990.

. Radiografia do Quadro Partidário Brasileiro. São Paulo, Fundação Konrad Adenauer-Stiftung, 1993.

"Governabilidade, estrutura institucional e processo decisório no Brasil". Parcerias Estratégicas, v.1, n.3, jun. 1997, p.19-37.

. "Democratization through transition: the case of Brazil". In: NEWMAN, E. e GARRETON, M.A. (eds.). Democracy in Latin America. Tokyo, United Nations University Press (no prelo).

KINZO, M.D.G. e SILVA, S. R. "Politics in Brazil: the Cardoso's government and the 1988 re-election". Government and Opposition, v.34, n.2, 1999, p.243-62. 
LAMOUNIER, B. “O discurso e o processo - Da distensão às opções do regime brasileiro". In: RATTNER, H. (org.). Brasil 1980. Caminhos alternativos do desenvolvimento. São Paulo, Brasiliense, 1979.

. “O 'Brasil autoritário' revisitado: o impacto das eleições sobre a abertura”. In: STEPAN, A. (ed.). Op. cit., 1988.

. "Brazil: inequality against democracy". In: DIAMOND, L. et alii (eds.). Democracy in developing countries - Latin America. Boulder, Ed. Lynne Reinner, 1989.

."Estrutura institucional e governabilidade na década de 90". In: VELLOSO, J.P.R. (org.). O Brasil e as reformas políticas. Rio de Janeiro, José Olympio, 1992.

LAMOUNIER, B. e MOURA, A. "Economic policy and political opening in Brazil". In: HARTLYN, J. e MORLEY, S. (eds.). Latin American political economy: financial crisis and political change. Boulder, Ed. Westview, 1986.

LINZ, J. "The future of an authoritarian situation or the institutionalization of an authoritarian regime: the case of Brazil". In: STEPAN, A. (ed.). Op.cit., 1973.

LONGO, C.A. "The state and the liberalization of the economy". In: KINZO, M.D.G. (ed.). Brazil: the challenges of the 1990's. London, British Academic Press, 1993.

MARTINS, L. "The liberalization of the authoritarian rule in Brazil". In: O’DONNELL, G.; SCHMITTER, P. e WHITEHEAD, L. (eds.). Transitions from authoritarian rule - Latin America. Baltimore/ Londres, Editora da Universidade John Hopkins, 1986.

NICOLAU, J. “A volatilidade eleitoral nas eleições para a Câmara dos Deputados brasileira (1992-1994)". XXII Encontro Anual da ANPOCS. Caxambu, out. 1998, mimeo.

PERES, P.S. "Sistema partidário, instabilidade eleitoral e consolidação democrática no Brasil". II Encontro Anual da Associação Brasileira de Ciência Política (ABCP), 2000, mimeo.
ROUQUIÉ, A. "Demilitarization and the institutionalization of militarydominated polities in Latin America". Working Papers of Latin America Program. Washington, Wilson Center, n.110, 1982.

SALLUM Jr., B. "O Brasil sob Cardoso: neoliberalismo e desenvolvimentismo". Tempo Social - Revista de Sociologia da USP. São Paulo, v.11, n.2, p.23-47, out. 1999.

SARTORI, G. Partidos e sistemas partidários. Rio de Janeiro/Brasília, Zahar/UNB, 1982.

SERRA, J. "Ciclos e mudanças estruturais na economia brasileira do pós-guerra". In: BELLUZZO, L. e COUTINHO, R. Desenvolvimento capitalista no Brasil-Ensaios sobre a crise. São Paulo, Brasiliense, 1982.

SKIDMORE, T. The politics of military rule in Brazil: 1964-1985. Oxford/Nova York, Oxford University Press, 1988.

SOUZA, A. e LAMOUNIER, B. "A feitura da nova constituição: um reexame da cultura política brasileira”. In: LAMOUNIER, B. (ed.). De Geisel a Collor: o balanço da transição. São Paulo, Ed. Sumaré, 1990.

STEPAN, A. (ed.). Authoritarian Brazil-Origins, policies and future. New Haven, Yale University Press, 1973.

. Os militares na politica. Rio de Janeiro, Ed. Artenova, 1975. . (ed.). Democratizando o Brasil. Rio de Janeiro, Paz e Terra, 1988 .

SUZIGAN, W. et alii. Crescimento industrial no Brasil. Rio de Janeiro, Ipea, 1974.

TSEBELIS, G. "Decision-Making in political system: veto players in presidentialism, parlamentarism, multicameralism and multipartysim". British Journal of Political Science, v.25, 1995, p.289-325.

VELASCO E CRUZ, S. e MARTINS, C.E. "De Castelo a Figueiredo: uma incursão na pré-história da 'Abertura'". In: SORJ, B. e ALMEIDA, M.H.T. (eds.). Sociedade e politica no Brasil pós-64. São Paulo, Brasiliense, 1983. 